\title{
Molecular Weight Control of Polyethylene Waxes using a Constrained Imino- Cyclopenta[b]pyridyl-Nickel Catalyst
}

\author{
Zheng Wang, ${ }^{a, b}$ Youfu Zhang, ${ }^{b, c}$ Yanping Ma, ${ }^{a}$ Xinquan Hu, ${ }^{*, c}$ Gregory A. Solan, ${ }^{*, b, d,}$ Yang Sun, ${ }^{a}$ and \\ Wen-Hua Sun*,a,b
}

(Zheng Wang and Youfu Zhang made an equal contribution in this work.)

${ }^{a}$ Key Laboratory of Engineering Plastics and Beijing National Laboratory for Molecular Science, Institute of Chemistry, Chinese Academy of Sciences, Beijing 100190, China.

${ }^{\mathrm{b}}$ CAS Research/Education Center for Excellence in Molecular Sciences, University of Chinese Academy of Sciences, Beijing 100049, China.

${ }^{c}$ College of Chemical Engineering, Zhejiang University of Technology, Hangzhou 310014, China.

${ }^{\mathrm{d}}$ Department of Chemistry, University of Leicester, University Road, Leicester LE1 7RH, UK.

Correspondence to: W.-H. Sun (E-mail:whsun@iccas.ac.cn; xinquan@zjut.edu.cn; gas8@le.ac.uk)

ABSTRACT: Five examples of nickel(II) bromide complexes bearing $\mathrm{N}, \mathrm{N}$-iminocyclopenta[b]pyridines, [7-(ArN)-6- $\mathrm{Me}_{2} \mathrm{C}_{8} \mathrm{H}_{5} \mathrm{~N}$ ] $\mathrm{NiBr}_{2}\left(\mathrm{Ar}=2,6-\mathrm{Me}_{2} \mathrm{C}_{6} \mathrm{H}_{3}\right.$ (Ni1), 2,6- $\mathrm{Et}_{2} \mathrm{C}_{6} \mathrm{H}_{3}$ (Ni2), 2,6-i$\mathrm{Pr}_{2} \mathrm{C}_{6} \mathrm{H}_{3}$ (Ni3), 2,4,6- $\mathrm{Me}_{3} \mathrm{C}_{6} \mathrm{H}_{2}$ (Ni4), 2,6- $-\mathrm{Et}_{2}-4-\mathrm{MeC}_{6} \mathrm{H}_{2}$ (Ni5)), have been prepared by the reaction of the corresponding ligand, $\mathbf{L 1}-\mathbf{L} \mathbf{5}$, with $\mathrm{NiBr}_{2}(\mathrm{DME})$ (DME = 1,2-dimethoxyethane). On crystallization from bench dichloromethane, Ni1 underwent adventitious reaction with water to give the aqua salt, $\left[\mathrm{L1NiBr}\left(\mathrm{OH}_{2}\right)_{3}\right][\mathrm{Br}](\mathbf{N i 1})$. The molecular structures of $\mathbf{N i 1}$ and $\mathbf{N i 3}$ have been structurally characterized, the latter revealing a bromide-bridged dimer. On activation with either MMAO or $\mathrm{Et}_{2} \mathrm{AlCl}, \mathbf{N i 1}, \mathbf{N i 2}, \mathbf{N i 4}$ and $\mathbf{N i 5}$, all exhibited high activities for ethylene polymerization (up to $3.88 \times$ $\left.10^{6} \mathrm{~g}(\mathrm{PE}) \cdot \mathrm{mol}^{-1}(\mathrm{Ni}) \cdot \mathrm{h}^{-1}\right)$; the most sterically bulky $\mathrm{Ni3}$ gave only low activity. Polyethylene waxes are a feature of the materials obtained which typically display low molecular weights, narrow molecular weight distributions and unsaturated vinyl and vinylene functionalities. Notably, the catalyst comprising Ni1/Et ${ }_{2} \mathrm{AlCl}$ produced polyethylene with the lowest molecular weight, $0.67 \mathrm{Kg} \cdot \mathrm{mol}^{-1}$, which is less than any previously reported data for any class of cycloalkyl-fused pyridine-nickel catalyst.

KEYWORDS: N,N-imino-cyclopenta[b]pyridines; Polyethylene; coordination/insertion polymerization; nickel complex.

\section{INTRODUCTION}

Since the first report of $\alpha$-diimino-nickel precatalysts in ethylene polymerization in the mid1990 's, ${ }^{1}$ the intervening years have seen numerous developments in catalyst design that have impacted on a wide range of properties such as catalyst activity, molecular weight of the polyethylene through to the distribution of oligomer/polymer. ${ }^{2}$ In addition, the degree of branching within the polymer can be influenced by the choice of nickel catalyst to the point that the resultant materials can sometimes show properties reminiscent of linear low density polyethylene. ${ }^{2,3}$ Central to these performance and structural variations is the nature of the 
ancillary ligand with bidentate, $\mathrm{N}^{\wedge} \mathrm{N},{ }^{4} \mathrm{~N}^{\wedge} \mathrm{O}^{5}$ and $\mathrm{N}^{\wedge} \mathrm{P}^{6}$ as well as tridentate ligands, $\mathrm{N}^{\wedge} \mathrm{N}^{\wedge} \mathrm{N},{ }^{7}$ $\mathrm{N}^{\wedge} \mathrm{P}^{\wedge} \mathrm{N}^{8}, \mathrm{O}^{\wedge} \mathrm{N}^{\wedge} \mathrm{N}^{9}$ and $\mathrm{P}^{\wedge} \mathrm{N}^{\wedge} \mathrm{P}^{10}$ commonly employed.
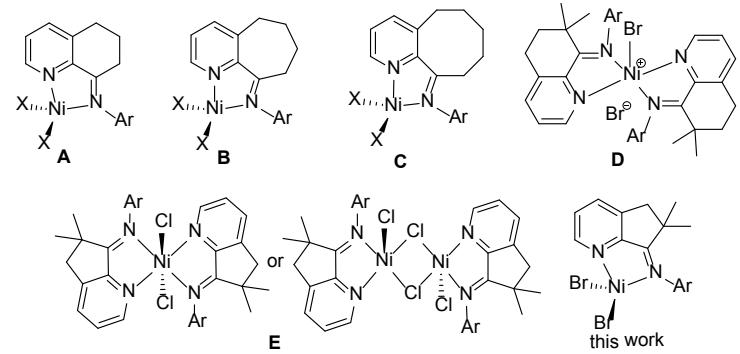

Chart 1. Previous and to be developed cycloalkylfused pyridyl-nickel pre-catalysts (A - E)

Recent years have seen the introduction of cycloalkyl-fused pyridines as compatible $\mathrm{N}, \mathrm{N}$ ligand frames for nickel with some examples including the cyclohexyl-, cycloheptyl- and cyclooctyl-derivatives $\mathbf{A},{ }^{11} \mathbf{B}^{12}$ and $\mathbf{C}$, respectively (Chart 1). ${ }^{13}$ Indeed $\mathbf{A}$ - $\mathbf{C}$ exhibit high activities in ethylene polymerization generating polyethylenes of generally low molecular weight but with their specific range depending on the ring size. ${ }^{11 a, 11 b, 12,13}$ To address issues associated with undesirable imine-enamine tautomerization processes that have affected some of these cycloalkyl-fused systems, ${ }^{14}$ the gem-dimethyl cyclohexyl-containing $\mathbf{D}^{15}$ (Chart 1 ) has been subsequently disclosed. ${ }^{16}$ While the activity of $\mathbf{D}$ is lower when compared to its closest comparator $\mathbf{A}$, it displays slightly lower molecular weight and a narrower molecular weight distribution for the polymer. Subsequently, the more strained 6,6-dimethyliminocyclopenta[b]pyridyl-nickel chlorides (E, Chart 1$)^{16}$ have been developed that generate polyethylenes with even lower molecular weight, narrower polydispersities and contain vinyl and vinylene groups. To the best of our knowledge, $\mathbf{E}$ is the first of its kind to promote the formation of vinyl- and vinylenepolyethylenes by an ethylene homopolymerization process. With regard to steric effects, ${ }^{17}$ all the cycloalkyl-fused pyridine systems, A - E, give enhanced catalytic performance with less sterically hindered $\mathrm{N}$-aryl groups. On the other hand electronic factors can show some notable differences. For example, electron donating groups at the para-position of the $\mathrm{N}$-aryl group enhance catalytic performance for $\mathbf{B}$ and $\mathbf{C}$ while for $\mathbf{A}$ and $\mathbf{E}$ the opposite trend is observed. ${ }^{11 a, 12 a, 13}$

Given the unusual properties of the polymer exhibited with $\mathbf{E}$ as the pre-catalyst and the sensitivity of cycloalkyl-pyridine ligand frame to steric and electronic variations, we decided to re-examine the polymerization using a slightly modified pre-catalyst. In particular, we explore in this work the catalytic performance of the 1:1 6,6-dimethyl-7-aryliminocyclopenta[b]pyridylnickel bromides (Chart 1) in ethylene polymerization. Notably, in previous work we have noted that the nature of the halide ligand in the pre-catalyst can influence to some degree both the activity and molecular weight. ${ }^{11-13} \mathrm{~A}$ detailed catalytic evaluation will be reported while full synthetic and characterization data will be disclosed.

\section{EXPERIMENTAL}

General Considerations. All manipulations involving air- and/or moisture-sensitive compounds were performed under an atmosphere of nitrogen using standard Schlenk techniques. Prior to use, toluene was refluxed over sodium-benzophenone and distilled under an atmosphere of nitrogen. Methylaluminoxane (MAO, $1.46 \mathrm{M}$ in toluene) and modified methylaluminoxane (MMAO, $1.93 \mathrm{M}$ in $n$ heptane) were purchased from Akzo Nobel Corp. Diethylaluminum chloride $\left(\mathrm{Et}_{2} \mathrm{AlCl}, 1.17 \mathrm{M}\right.$ in toluene) and ethylaluminum sesquichloride (EASC, $0.87 \mathrm{M}$ in $n$-hexane) were purchased from Acros Chemicals. High-purity ethylene was purchased from Beijing Yanshan Petrochemical Co. and used as received. Other reagents were purchased from Aldrich, Acros or local suppliers. IR spectra were recorded on a Perkin-Elmer System 2000 FT-IR spectrometer. Elemental analysis was carried out using a Flash EA 1112 microanalyzer. Molecular weights $\left(M_{\mathrm{w}}\right)$ and molecular weight distributions $\left(M_{\mathrm{w}} / M_{\mathrm{n}}\right)$ of the polyethylenes were determined using a PLGPC220 instrument at $150{ }^{\circ} \mathrm{C}$ with $1,2,4$ - 
trichlorobenzene as the solvent. The melting temperatures $\left(T_{\mathrm{m}}\right)$ of the polyethylenes were measured from the second scanning run on a PerkinElmer TA-Q2000 differential scanning calorimeter (DSC) under a nitrogen atmosphere. In the procedure, a sample of about $5.0 \mathrm{mg}$ was heated to $140{ }^{\circ} \mathrm{C}$ at a rate of $20^{\circ} \mathrm{C} / \mathrm{min}$ and kept for $2 \mathrm{~min}$ at $140{ }^{\circ} \mathrm{C}$ to remove the thermal history and then cooled at a rate of $20^{\circ} \mathrm{C} / \mathrm{min}$ to $-40{ }^{\circ} \mathrm{C} .{ }^{1} \mathrm{H}$ NMR, ${ }^{13} \mathrm{C}$ NMR and DEPT $135{ }^{13} \mathrm{C}$ NMR spectra of the polyethylenes were recorded on a Bruker DMX $300 \mathrm{MHz}$ instrument at $100{ }^{\circ} \mathrm{C}$ in deuterated 1,1,2,2-tetrachloroethane with TMS as an internal standard. The iminocyclopenta[b]pyridines, 7-( $\mathrm{ArN})-6-\mathrm{Me}_{2} \mathrm{C}_{8} \mathrm{H}_{5} \mathrm{~N}(\mathrm{Ar}$ $=$ 2,6- $-\mathrm{Me}_{2} \mathrm{C}_{6} \mathrm{H}_{3} \quad$ (L1), 2,6- $\mathrm{Et}_{2} \mathrm{C}_{6} \mathrm{H}_{3} \quad$ (L2), 2,6-i$\mathrm{Pr}_{2} \mathrm{C}_{6} \mathrm{H}_{3} \quad$ (L3), 2,4,6- $\mathrm{Me}_{3} \mathrm{C}_{6} \mathrm{H}_{2} \quad$ (L4), 2,6- $-\mathrm{Et}_{2}-4-$ $\mathrm{MeC}_{6} \mathrm{H}_{2}$ (L5)), were prepared using previously reported procedures. ${ }^{16}$

\section{Synthesis of nickel complexes}

[7-\{(2,6- $\left.\left.\left.-\mathrm{Me}_{2} \mathrm{C}_{6} \mathrm{H}_{3}\right) \mathrm{N}\right\}-6-\mathrm{Me}_{2} \mathrm{C}_{8} \mathrm{H}_{5} \mathrm{~N}\right] \mathrm{NiBr}_{2}$ (Ni1). $\mathrm{NiBr}_{2}$ (DME) (0.083 g, $0.27 \mathrm{mmol}$ ) was added to a solution of $\mathbf{L 1}(0.079 \mathrm{~g}, 0.30 \mathrm{mmol})$ in $\mathrm{CH}_{2} \mathrm{Cl}_{2}$ $(10 \mathrm{~mL})$. The mixture was stirred for $12 \mathrm{~h}$ and then diethyl ether poured into the mixture to precipitate the complex. The precipitate was collected by filtration, washed with diethyl ether and dried under reduced pressure at $50{ }^{\circ} \mathrm{C}$ for $3 \mathrm{~h}$ to give $\mathrm{Ni1}$ as a red powder $(0.120$ g, 93\%). FT-IR (KBr, cm$\left.{ }^{-1}\right): 2979(\mathrm{w}), 2918(\mathrm{w})$, $2873(\mathrm{w}), 1631\left(v_{\mathrm{C}=\mathrm{N}}, \mathrm{s}\right), 1608(\mathrm{~s}), 1456(\mathrm{~s}), 1432$ (m), $1378(w), 1298(\mathrm{~m}), 1174(\mathrm{~s}), 1022(\mathrm{w}), 879$ (w), 795 (vs). Anal. Calcd for $\mathrm{C}_{18} \mathrm{H}_{20} \mathrm{Br}_{2} \mathrm{~N}_{2} \mathrm{Ni}$ : C, 44.77; H, 4.17; N, 5.80. Found: C, 44.32; H, 4.30; N, 5.68 .

\section{[7- $\left.\left\{\left(2,6-\mathrm{Et}_{2} \mathrm{C}_{6} \mathrm{H}_{3}\right) \mathrm{N}\right\}-6-\mathrm{Me}_{2} \mathrm{C}_{8} \mathrm{H}_{5} \mathrm{~N}\right] \mathrm{NiBr}_{2}$} Using a procedure similar to that described for Ni1 but with L2 in place of L1, Ni2 was isolated as an orange powder $(0.122 \mathrm{~g}, 89 \%)$. FT-IR $(\mathrm{KBr}$, $\left.\mathrm{cm}^{-1}\right)$ : $2973(\mathrm{w}), 2930(\mathrm{w}), 2876(\mathrm{w}), 1634\left(v_{\mathrm{C}=\mathrm{N}}\right.$, s), $1610(\mathrm{~s}), 1451(\mathrm{~s}), 1432(\mathrm{~m}), 1331(\mathrm{~m}), 1296$ (m), 1169 (s), 1023 (w), 881 (w), 798 (vs). Anal. Calcd for $\mathrm{C}_{20} \mathrm{H}_{24} \mathrm{Br}_{2} \mathrm{~N}_{2} \mathrm{Ni}: \mathrm{C}, 47.02 ; \mathrm{H}, 4.73 ; \mathrm{N}$, 5.48. Found: $\mathrm{C}, 47.13 ; \mathrm{H}, 4.92 ; \mathrm{N}, 5.25$.

$\left[7-\left\{\left(2,6-i-\mathrm{Pr}_{2} \mathrm{C}_{6} \mathrm{H}_{3}\right) \mathrm{N}\right\}-6-\mathrm{Me}_{2} \mathrm{C}_{8} \mathrm{H}_{5} \mathrm{~N}\right] \mathrm{NiBr}_{2}$

(Ni3).
Using a procedure similar to that described for Ni1 but with L3 in place of L1, Ni3 was isolated as a red powder $(0.127 \mathrm{~g}, 88 \%)$. FT-IR $\left(\mathrm{KBr}, \mathrm{cm}^{-}\right.$ $\left.{ }^{1}\right)$ : $2961(\mathrm{~m}), 2935(\mathrm{w}), 2864(\mathrm{w}), 1631\left(v_{\mathrm{C}=\mathrm{N}}, \mathrm{s}\right)$, 1606 (s), 1454 (s), $1439(\mathrm{~m}), 1362(\mathrm{w}), 1298(\mathrm{~m})$, 1170 (s), 1023 (w), 879 (w), 803 (s). Anal. Calcd for $\mathrm{C}_{22} \mathrm{H}_{28} \mathrm{Br}_{2} \mathrm{~N}_{2} \mathrm{Ni}$ : C, 49.03; $\mathrm{H}, 5.24 ; \mathrm{N}, 5.20$. Found: $\mathrm{C}, 48.77 ; \mathrm{H}, 4.92 ; \mathrm{N}, 5.40$.

[7-\{(2,4,6- $\left.\left.\left.-\mathrm{Me}_{3} \mathrm{C}_{6} \mathrm{H}_{2}\right) \mathrm{N}\right\}-6-\mathrm{Me}_{2} \mathrm{C}_{8} \mathrm{H}_{5} \mathrm{~N}\right] \mathrm{NiBr}_{2}$ (Ni4). Using a procedure similar to that described for Ni1 but with L4 in place of L1, Ni4 was isolated as a red powder $(0.124 \mathrm{~g}, 93 \%)$. FT-IR $\left(\mathrm{KBr}, \mathrm{cm}^{-}\right.$ $\left.{ }^{1}\right): 2960(w), 2923(w), 2866(w), 1635\left(v_{C=N}, s\right)$, $1617(\mathrm{~s}), 1455(\mathrm{~m}), 1429(\mathrm{w}), 1378(\mathrm{w}), 1214(\mathrm{w})$, $1187(\mathrm{w}), 1022(\mathrm{~m}), 888(\mathrm{~m}), 802(\mathrm{~s})$. Anal. Calcd for $\mathrm{C}_{19} \mathrm{H}_{22} \mathrm{Br}_{2} \mathrm{~N}_{2} \mathrm{Ni}$ : C, 45.93; $\mathrm{H}, 4.46 ; \mathrm{N}, 5.64$. Found: C, 45.43; H, 4.87; N, 5.44.

\section{[7-\{(2,6-Et $\left.\left.\left.2-4-\mathrm{MeC}_{6} \mathrm{H}_{2}\right) \mathrm{N}\right\}-6-\mathrm{Me}_{2} \mathrm{C}_{8} \mathrm{H}_{5} \mathrm{~N}\right] \mathrm{NiBr}_{2}$}

(Ni5). Using a procedure similar to that described for Ni1 but with L5 in place of L1, Ni5 was isolated as an orange powder $(0.135 \mathrm{~g}$, 95\%). FT-IR $\left(\mathrm{KBr}, \mathrm{cm}^{-1}\right): 2971(\mathrm{w}), 2927(\mathrm{w})$, $2873(\mathrm{w}), 1636\left(v_{\mathrm{C}=\mathrm{N}}, \mathrm{s}\right), 1609(\mathrm{~m}), 1457(\mathrm{~s}), 1433$ $(w), 1334(m), 1296(w), 1165(w), 1022(w), 881$ (w), 858 (m), 797 (s). Anal. Calcd for $\mathrm{C}_{21} \mathrm{H}_{26} \mathrm{Br}_{2} \mathrm{~N}_{2} \mathrm{Ni}$ : C, 48.05; $\mathrm{H}, 4.99 ; \mathrm{N}, 5.34$. Found: C, 48.44; H, 4.79; N, 5.57.

\section{Ethylene polymerization at $\mathbf{5 / 1 0}$ atm ethylene} pressure. The polymerization at high ethylene pressure was carried out in a stainless steel autoclave ( $250 \mathrm{~mL}$ capacity) equipped with an ethylene pressure control system, a mechanical stirrer and a temperature controller. The autoclave atmosphere was evacuated and the autoclave was filled with ethylene three times. When the desired reaction temperature was reached, $30 \mathrm{~mL}$ of toluene (freshly distilled) was added under ethylene atmosphere and the solution of the nickel pre-catalyst ( $\mathrm{Ni1}-\mathrm{Ni5}$ ) in another toluene $(50 \mathrm{~mL})$ was injected. The required amount of co-catalyst (MAO, MMAO, $\left.\mathrm{EtAlCl}_{2}, \mathrm{EASC}\right)$ and additional toluene $(20 \mathrm{~mL})$ were added by syringe successively. Then the ethylene pressure was increased to the desired value and the stirring initiated. After the required reaction time, the reactor was cooled

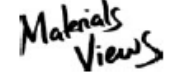

WWW.MATERIALSVIEWS.COM 
with an ice-water bath and the excess ethylene was vented. The resultant mixture was poured into $10 \%$ solution of $\mathrm{HCl}$ in ethanol, and the polymer was collected and washed with ethanol several times and dried in vacuo to constant weight.

\section{X-ray crystallographic study}

Single crystals of Ni1' and $\mathbf{N i 3}$ suitable for X-ray diffraction were obtained by slow diffusion of diethyl ether into a dichloromethane solution of the corresponding complex at room temperature. X-ray studies were carried out on a Rigaku Saturn724 + CCD with graphitemonochromatic Mo-K $\alpha$ radiation $(\lambda=0.71073 \AA$ ) at $173(2) \mathrm{K}$; cell parameters were obtained by global refinement of the positions of all collected reflections. Intensities were corrected for Lorentz and polarization effects and empirical absorption. The structures were solved by direct methods and refined by fullmatrix least squares on $F^{2}$. All hydrogen atoms were placed in calculated positions. Structure solution and refinement were performed by using the SHELXL-97 package. ${ }^{18}$ Details of the Xray structure determinations and refinements are provided in Table 1.

Table 1 Crystal data and structure refinement for Ni1' and $\mathbf{N i 3}$

\begin{tabular}{|c|c|c|}
\hline & Ni1' & $\mathrm{Ni3}$ \\
\hline Empirical formula & $\mathrm{C}_{18} \mathrm{H}_{26} \mathrm{Br}_{2} \mathrm{~N}_{2} \mathrm{NiO}_{3}$ & $\mathrm{C}_{44} \mathrm{H}_{56} \mathrm{Br}_{4} \mathrm{~N}_{4} \mathrm{Ni}_{2}$ \\
\hline Formula weight & 536.93 & 1077.99 \\
\hline Temperature/K & $173(2)$ & $173(2)$ \\
\hline Wavelength/Å & 0.71073 & 0.71073 \\
\hline Crystal system & triclinic & triclinic \\
\hline space group & $P-1$ & $P-1$ \\
\hline $\mathrm{a} / \AA$ & $8.2799(17)$ & $9.6080(19)$ \\
\hline $\mathrm{b} / \AA \AA$ & $8.7003(17)$ & $12.672(3)$ \\
\hline$c / \AA ̊$ & $15.655(3)$ & $18.524(4)$ \\
\hline$\alpha /{ }^{\circ}$ & $76.36(3)$ & $103.25(3)$ \\
\hline$\beta /^{\circ}$ & $80.94(3)$ & $91.58(3)$ \\
\hline $\mathrm{y}^{\circ}$ & 75.15 (3) & 99.53 (3) \\
\hline Volume $/ \AA^{3}$ & $1053.7(4)$ & $2160.0(7)$ \\
\hline
\end{tabular}

\begin{tabular}{|c|c|c|}
\hline Z & 2 & 2 \\
\hline$D_{\text {calcd }} /\left(\mathrm{g} \mathrm{cm}^{-3}\right)$ & 1.689 & 1.657 \\
\hline$\mu / \mathrm{mm}^{-1}$ & 4.732 & 4.607 \\
\hline$F(000)$ & 538.0 & 1088.0 \\
\hline Crystal size/mm & $\begin{array}{l}0.489 \times 0.243 \times \\
0.115\end{array}$ & $\begin{array}{l}0.303 \times 0.207 \\
\times 0.182\end{array}$ \\
\hline$\theta$ range $/^{\circ}$ & 4.94 to 54.98 & 2.26 to 54.96 \\
\hline Limiting indices & $\begin{array}{l}-10 \leq \mathrm{h} \leq 10 \\
-11 \leq \mathrm{k} \leq 11 \\
-20 \leq \mathrm{I} \leq 20\end{array}$ & $\begin{array}{l}-12 \leq \mathrm{h} \leq 12 \\
-16 \leq \mathrm{k} \leq 16 \\
-24 \leq \mathrm{I} \leq 24\end{array}$ \\
\hline No. of rflns collected & 10399 & 24079 \\
\hline No. unique rflns $[R(\mathrm{int})]$ & $4709(0.0415)$ & $9706(0.0214)$ \\
\hline Completeness to $\theta$ & $97.0 \%$ & $98.0 \%$ \\
\hline Data/restraints/parameters & $4709 / 0 / 250$ & $9706 / 0 / 509$ \\
\hline Goodness of fit on $F^{2}$ & 1.071 & 1.066 \\
\hline Final $R$ indices $[I>2 \Sigma(I)]$ & $\begin{array}{l}R_{1}=0.0372 \\
w R_{2}=0.0887\end{array}$ & $\begin{array}{l}R_{1}=0.0277 \\
w R_{2}=0.0672\end{array}$ \\
\hline$R$ indices (all data) & $\begin{array}{l}R_{1}=0.0340 \\
\mathrm{w} R_{2}=0.0900\end{array}$ & $\begin{array}{l}R_{1}=0.0300 \\
w R_{2}=0.0686\end{array}$ \\
\hline $\begin{array}{l}\text { Largest diff. peak and hole } \\
\left(\mathrm{e} \AA^{-3}\right)\end{array}$ & $0.88 /-0.77$ & $0.65 /-0.61$ \\
\hline
\end{tabular}

The SQUEEZE option of the crystallographic program PLATON was used to remove free solvent from the structures of $\mathrm{Ni}^{\prime}$ and $\mathrm{Ni3}$. Details of the X-ray structure determinations and refinements are provided in Table 1. CCDC 1554536 (Ni1') and 1554537(Ni3.) contain the crystallographic data for this article, which could be obtained free of charge from the Cambridge Crystallographic Data Centre via www.ccdc.cam.ac.uk/ data_request/cif.

\section{RESULTS AND DISCUSSION}

Synthesis and characterization Reaction of the imino-cyclopenta[b]pyridines, 7-(ArN)-6$\mathrm{Me}_{2} \mathrm{C}_{8} \mathrm{H}_{5} \mathrm{~N}$ ( $\mathrm{Ar}=2,6-\mathrm{Me}_{2} \mathrm{C}_{6} \mathrm{H}_{3}$ (L1), 2,6- $-\mathrm{Et}_{2} \mathrm{C}_{6} \mathrm{H}_{3}$ (L2), 2,6-i- $\mathrm{Pr}_{2} \mathrm{C}_{6} \mathrm{H}_{3}$ (L3), 2,4,6- $\mathrm{Me}_{3} \mathrm{C}_{6} \mathrm{H}_{2}$ (L4), 2,6$\mathrm{Et}_{2}-4-\mathrm{MeC}_{6} \mathrm{H}_{2}$ (L5)), with $\mathrm{NiBr}_{2}$ (DME) in dichloromethane affords the corresponding nickel complexes, [7-(ArN)-6- $\left.\mathrm{Me}_{2} \mathrm{C}_{8} \mathrm{H}_{5} \mathrm{~N}\right] \mathrm{NiBr}_{2}$ (Ni1 - Ni5) in excellent yields (Scheme 1). The synthetic procedures for $\mathbf{L} \mathbf{1}$ - L5, involving the condensation of 2-chloro-6,6-dimethylcyclopenta[b]pyridin-7-one with the corresponding aniline, have been reported previously. ${ }^{16}$ All five complexes have been characterized using IR spectroscopy and 
elemental analysis while $\mathbf{N i 1}$ and $\mathbf{N i 3}$ have been the subject of single crystal X-ray diffraction studies.
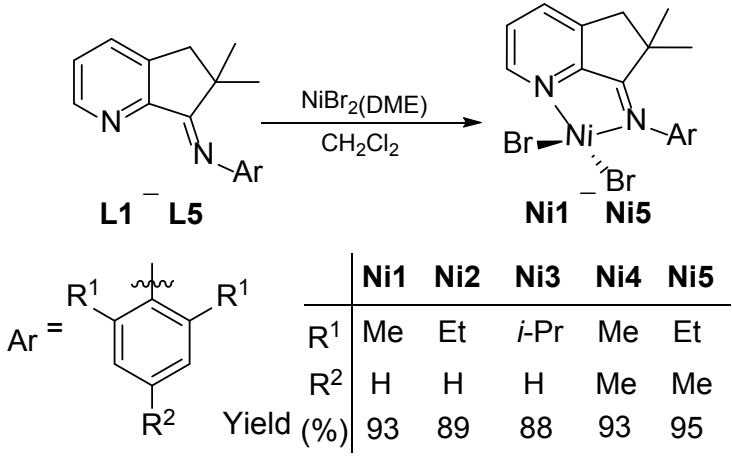

\section{Scheme 1 Synthetic procedure for Ni1 - Ni5}

Single crystals of Ni1 and Ni3 suitable for Xray determination were grown by slow diffusion of diethyl ether into a dichloromethane solution of the corresponding complex at room temperature. The molecular structures are shown in Figs. 1 and 2, respectively; selected bond lengths and angles are compiled in Table 2 Examination of the structure shown in Fig. 1, reveals a cation-anion pair of composition [ $\left.\mathrm{L} 1 \mathrm{NiBr}\left(\mathrm{OH}_{2}\right)_{3}\right][\mathrm{Br}]\left(\mathbf{N i 1} \mathbf{1}^{\prime}\right)$. Its apparent that one of the bromide ligands in $\mathrm{Ni1}$ has dissociated with the result that it now acts a noncoordinating anion, while three molecules of

Table 2 Selected bond lengths $(\AA)$ and angles $\left({ }^{\circ}\right)$ for $\mathbf{N i 1}$ ' and $\mathbf{N i 3}$

\begin{tabular}{llll}
\hline \multicolumn{4}{c}{$\mathrm{Ni1} 1^{c} \mathrm{Ni3}$} \\
\hline \multicolumn{4}{c}{ Bond lengths $(\AA)$} \\
$\mathrm{Ni}(1)-\mathrm{N}(1)$ & $2.1670(2)$ & $\mathrm{Ni}(1)-\mathrm{N}(1)$ & $2.1454(15)$ \\
$\mathrm{Ni}(1)-\mathrm{N}(2)$ & $2.0693(19)$ & $\mathrm{Ni}(1)-\mathrm{N}(2)$ & $2.0555(15)$ \\
$\mathrm{Ni}(1)-\mathrm{Br}(1)$ & $2.5771(9)$ & $\mathrm{Ni}(1)-\mathrm{Br}(1)$ & $2.5186(8)$ \\
$\mathrm{Ni}(1)-\mathrm{O}(1)$ & $2.0443(17)$ & $\mathrm{Ni}(1)-\mathrm{Br}\left(1^{\prime}\right)$ & $2.5080(7)$ \\
$\mathrm{Ni}(1)-\mathrm{O}(2)$ & $2.0718(16)$ & $\mathrm{Ni}(1)-\mathrm{Br}(2)$ & $2.4032(8)$ \\
$\mathrm{Ni}(1)-\mathrm{O}(3)$ & $2.0789(16)$ & & \\
& \multicolumn{3}{c}{$\mathrm{Bond}$ angles $\left(^{\circ}\right)$} \\
$\mathrm{N}(1)-\mathrm{Ni}(1)-\mathrm{N}(2)$ & $81.29(8)$ & $\mathrm{Br}(1)-\mathrm{Ni}(1)-\mathrm{O}(3)$ & $88.48(5)$ \\
$\mathrm{N}(1)-\mathrm{Ni}(1)-\mathrm{Br}(1)$ & $178.36(5)$ & $\mathrm{O}(2)-\mathrm{Ni}(1)-\mathrm{O}(3)$ & $175.09(6)$ \\
$\mathrm{N}(1)-\mathrm{Ni}(1)-\mathrm{O}(1)$ & $88.22(7)$ & $\mathrm{N}(1)-\mathrm{Ni}(1)-\mathrm{N}(2)$ & $81.01(6)$ \\
$\mathrm{N}(1)-\mathrm{Ni}(1)-\mathrm{O}(2)$ & $92.28(7)$ & $\mathrm{N}(1)-\mathrm{Ni}(1)-\mathrm{Br}(1)$ & $141.40(4)$ \\
$\mathrm{N}(1)-\mathrm{Ni}(1)-\mathrm{O}(3)$ & $92.34(7)$ & $\mathrm{N}(1)-\mathrm{Ni}(1)-\mathrm{Br}(2)$ & $104.59(4)$ \\
$\mathrm{N}(2)-\mathrm{Ni}(1)-\mathrm{Br}(1)$ & $97.32(6)$ & $\mathrm{N}(1)-\mathrm{Ni}(1)-\mathrm{Br}\left(1^{i}\right)$ & $95.50(4)$ \\
$\mathrm{N}(2)-\mathrm{Ni}(1)-\mathrm{O}(1)$ & $169.16(7)$ & $\mathrm{N}(2)-\mathrm{Ni}(1)-\mathrm{Br}(1)$ & $90.41(5)$ \\
$\mathrm{N}(2)-\mathrm{Ni}(1)-\mathrm{O}(2)$ & $90.87(7)$ & $\mathrm{N}(2)-\mathrm{Ni}(1)-\mathrm{Br}(2)$ & $90.17(5)$
\end{tabular}

$\mathrm{N}(2)-\mathrm{Ni}(1)-\mathrm{O}(3) \quad 88.17(7) \quad \mathrm{N}(2)-\mathrm{Ni}(1)-\mathrm{Br}\left(1^{i}\right) \quad 169.01(4)$ $\mathrm{Br}(1)-\mathrm{Ni}(1)-\mathrm{O}(1) \quad 93.20(6) \quad \mathrm{Br}(1)-\mathrm{Ni}(1)-\mathrm{Br}(2) \quad 113.06(3)$ $\mathrm{Br}(1)-\mathrm{Ni}(1)-\mathrm{O}(2) \quad 86.87(5)$

The ' $i$ ' atoms have been generated by symmetry.

water are bound to the remaining cationic nickel center. The distorted octahedral geometry in Ni1' at nickel is completed by the two nitrogen donors belonging to $\mathbf{L} \mathbf{1}$ and the remaining bromide ligand. Two of the water molecules are mutually trans (02-Ni1-O3 $\left.175.09(6)^{\circ}\right)$, while the other is trans to the

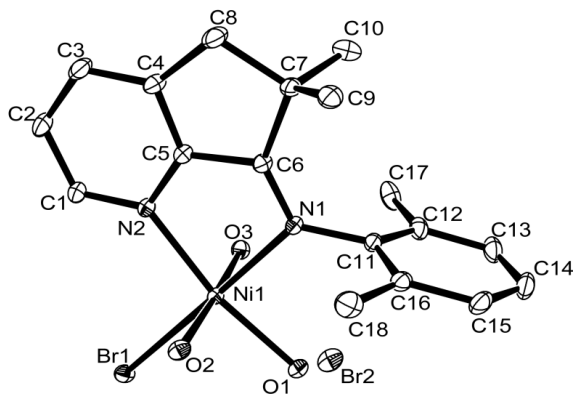

Fig. 1 ORTEP representation of cation-anion pair Ni1' with the thermal ellipsoids at $30 \%$ probability level; the $\mathrm{H}$ atoms are omitted for clarity.

pyridine nitrogen. The $\mathrm{Ni}-\mathrm{N}_{\text {pyridine }}$ bond (2.0693(19) $\AA$ ) is shorter than the $\mathrm{Ni}-\mathrm{N}_{\text {imino }}$ one $(2.1670(2) \AA)$, in a manner similar to that observed for analogous nickel complexes. ${ }^{11 d, 12 b, 15}$ The plane of the $\mathrm{N}_{\text {imino-aryl }}$ ring is inclined toward perpendicular with respect to the plane comprising N1, N2 and Ni1 with a dihedral angle of $87.24^{\circ}$.

Unlike Ni1, no adventitious reaction with water occurs on crystallization of $\mathrm{Ni3}$. Instead $\mathrm{Ni3}$ adopts a dimeric structure in which two bromide ligands bridge the metal centers while the other two bromides act as monodentate ligands. The five-coordinate geometry at each metal center is completed by the two nitrogen donors belonging to L3. Bromide-bridged structures are a well-known motif for $\mathrm{N}^{\wedge} \mathrm{N}$ nickel(II) halide complexes and indeed $\mathrm{Ni3}$ displays similar features to these literature reports. ${ }^{11 a, 11 b, 11 c, 12 a, 16,19}$ The five-coordinate geometry at each nickel center can be best described as distorted square-pyramidal 
geometry with $\mathrm{Br} 2$ forming the apex and $\mathrm{N} 1, \mathrm{~N} 2$, $\mathrm{Br} 1$ and $\mathrm{Br}{ }^{i}$ the square base. As with $\mathrm{Ni1}$ ', the $\mathrm{Ni}-\mathrm{N}_{\text {imino }}$ bond $(2.1454(15) \AA$ ) is noticeably longer than the $\mathrm{Ni}-\mathrm{N}_{\text {pyridine }}(2.0555(15) \AA$ distance, while the $\mathrm{N}$-aryl group is again oriented almost perpendicular to the plane defined by N1, N2 and Ni1 (dihedral angle of 83.53).

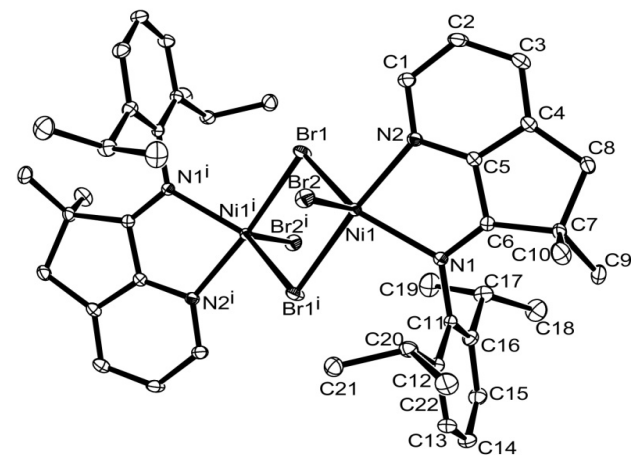

Fig. 2 ORTEP representation of complex $\mathrm{Ni3}$ with the thermal ellipsoids at $30 \%$ probability level; the $\mathrm{H}$ atoms are omitted for clarity.

All the complexes, Ni1 - Ni5, display $v_{\mathrm{C}=\mathrm{N}}$ stretching vibrations in the range of 1630 $1635 \mathrm{~cm}^{-1}$ in their IR spectra which compares to $1672-1680 \mathrm{~cm}^{-1}$ for the free ligands. ${ }^{16}$ This shift to lower wavenumber is consistent with effective coordination between the nickel and the imine nitrogen atom. Moreover, the microanalytical data for $\mathbf{N i 1} \mathbf{- ~} \mathbf{N i 5}$ are consistent with the proposed elemental composition.

\section{Ethylene Polymerization}

With the intention of determining the most suitable co-catalyst, $\mathrm{Ni4}$ was, in the first instance, explored as the test pre-catalyst with four different alkylaluminum reagents including methylaluminoxane (MAO), modified methylaluminoxane (MMAO), ethylaluminum sesquichloride $\left(\mathrm{Et}_{3} \mathrm{Al}_{2} \mathrm{Cl}_{2}, \mathrm{EASC}\right)$ and diethylaluminum chloride $\left(\mathrm{Et}_{2} \mathrm{AICl}\right)$. Typically the runs were performed at 30 oc under 10 atmospheres of ethylene pressure; the results are collected in Table 3. As a general observation all co-catalysts gave good activities for the polymerization with the values falling in the range $1.25-3.55 \times 10^{6} \mathrm{~g}(\mathrm{PE}) \cdot \mathrm{mol}^{-1}(\mathrm{Ni}) \cdot \mathrm{h}^{-1}$.
Table 3 Identification of the most suitable cocatalyst using $\mathbf{~ i 4}^{a}$

\begin{tabular}{|c|c|c|c|c|c|c|}
\hline Entry & Co-cat. & $\mathrm{Al} / \mathrm{Ni}$ & Act. $^{b}$ & $T_{\mathrm{m}}{ }^{\mathrm{C}} /{ }^{\circ} \mathrm{C}$ & $M_{\mathrm{w}}{ }^{d}$ & $M_{\mathrm{w}} / M_{\mathrm{n}}{ }^{d}$ \\
\hline 1 & MAO & 2000 & 1.25 & 97.2 & 1.25 & 1.53 \\
\hline 2 & MMAO & 2000 & 3.11 & 97.7 & 1.16 & 1.47 \\
\hline 3 & $\mathrm{Et}_{2} \mathrm{AICl}$ & 500 & 3.51 & 71.1 & 0.87 & 1.39 \\
\hline 4 & EASC & 500 & 1.86 & 80.0 & 1.03 & 1.43 \\
\hline
\end{tabular}

With MMAO and $\mathrm{Et}_{2} \mathrm{AICl}$ proving the most conducive to high activity, these two cocatalysts were selected for subsequent more detailed investigations. All polymers were characterized by gel permeation chromatography (GPC) and by differential scanning calorimetry (DSC).

\section{Polymerization screen using Ni1 - Ni5/MMAO}

With MMAO as the co-catalyst, Ni4 was used to establish the optimal $\mathrm{Al} / \mathrm{Ni}$ molar ratio, reaction temperature and reaction time; the results are listed in Table 4. Firstly, the effect of varying the molar ratios of $\mathrm{Al} / \mathrm{Ni}$ from 1500 to 2500 on Ni4 was examined with the temperature set at 30 oC and the run time at 30 minutes (entries $1-5$, Table 4). Inspection of the data reveals the highest activity of $3.88 \times 10^{6} \mathrm{~g}(\mathrm{PE}) \cdot \mathrm{mol}^{-1}(\mathrm{Ni}) \cdot \mathrm{h}^{-1}$ is obtained with an $\mathrm{Al} / \mathrm{Ni}$ molar ratio at 1750 (entry 2, Table 4). After this point the activity gradually decreases as the $\mathrm{Al} / \mathrm{Ni}$ molar ratio increases. However, in contrast to many related nickel catalysts, ${ }^{11 d, 20}$ there is a perceptible increase in the molecular weight of the polyethylenes as the $\mathrm{Al} / \mathrm{Ni}$ ratio increases, implying enhanced chain propagation over termination (Fig. 3); such a phenomenon has some limited precedent with nickel. ${ }^{21}$

Secondly, with the Al/Ni molar ratio fixed at 1750 , the temperature of the run was increased in ten degree increments from 20 to $50{ }^{\circ} \mathrm{C}$ (entries 2, 6 - 8, Table 4). The optimum temperature was observed as $30{ }^{\circ} \mathrm{C}$ (entry 2, Table 4). Raising the temperature further resulted in a sharp decrease in activity, this being attributed 
Table 4 Polymerization of ethylene in the presence of $\mathrm{MMAO}^{a}$

\begin{tabular}{|c|c|c|c|c|c|c|c|c|c|}
\hline Entry & Precat. & $\mathrm{Al} / \mathrm{Ni}$ & $T /{ }^{\circ} \mathrm{C}$ & $t / \mathrm{min}$ & $\mathrm{PE} / \mathrm{g}$ & Activity $^{b}$ & $T_{\mathrm{m}}{ }^{\mathrm{C}} /{ }^{\circ} \mathrm{C}$ & $M_{\mathrm{w}}{ }^{d} / \mathrm{Kg} \cdot \mathrm{mol}^{-1}$ & $M_{\mathrm{w}} / M_{\mathrm{n}}^{d}$ \\
\hline 1 & $\mathrm{Ni4}$ & 1500 & 30 & 30 & 3.98 & 2.65 & 97.7 & 1.12 & 1.47 \\
\hline 2 & $\mathrm{Ni} 4$ & 1750 & 30 & 30 & 5.82 & 3.88 & 95.6 & 1.11 & 1.43 \\
\hline 3 & $\mathrm{Ni} 4$ & 2000 & 30 & 30 & 4.67 & 3.11 & 97.7 & 1.16 & 1.47 \\
\hline 4 & $\mathrm{Ni} 4$ & 2250 & 30 & 30 & 3.77 & 2.51 & 98.4 & 1.19 & 1.46 \\
\hline 5 & $\mathrm{Ni} 4$ & 2500 & 30 & 30 & 3.33 & 2.22 & 98.7 & 1.21 & 1.47 \\
\hline 6 & $\mathrm{Ni4}$ & 1750 & 20 & 30 & 5.56 & 3.71 & 99.6 & 1.24 & 1.53 \\
\hline 7 & $\mathrm{Ni} 4$ & 1750 & 40 & 30 & 3.50 & 2.33 & 90.2 & 0.91 & 1.36 \\
\hline 8 & $\mathrm{Ni} 4$ & 1750 & 50 & 30 & 1.28 & 0.85 & 90.0 & 0.89 & 1.29 \\
\hline 9 & $\mathrm{Ni} 4$ & 1750 & 30 & 15 & 1.55 & 2.07 & 97.2 & 1.16 & 1.38 \\
\hline 10 & $\mathrm{Ni} 4$ & 1750 & 30 & 45 & 7.10 & 3.15 & 96.1 & 1.12 & 1.46 \\
\hline 11 & $\mathrm{Ni} 4$ & 1750 & 30 & 60 & 8.13 & 2.71 & 95.5 & 1.04 & 1.46 \\
\hline 12 & Ni1 & 1750 & 30 & 30 & 3.84 & 2.56 & 95.3 & 0.93 & 1.42 \\
\hline 13 & $\mathrm{Ni} 2$ & 1750 & 30 & 30 & 1.74 & 1.16 & 90.1 & 0.81 & 1.30 \\
\hline 14 & $\mathrm{Ni3}$ & 1750 & 30 & 30 & trace & - & - & - & - \\
\hline 15 & Ni5 & 1750 & 30 & 30 & 1.94 & 1.29 & 92.1 & 0.92 & 1.30 \\
\hline $16^{e}$ & $\mathrm{Ni} 4$ & 1750 & 30 & 30 & 1.57 & 1.05 & 91.0 & 1.01 & 1.42 \\
\hline
\end{tabular}

GPC; ${ }^{2} 5 \mathrm{~atm}$. ethylene

to both the instability of the active species and the lower solubility of ethylene in toluene at higher temperature. ${ }^{4 a, 11 a, 17 c, 22}$

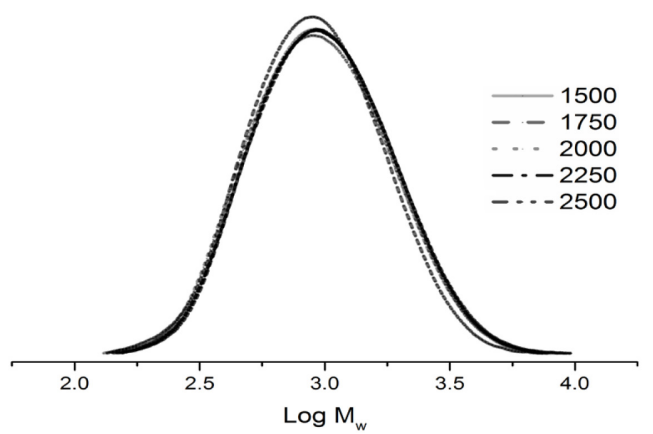

Fig. 3 GPC curves for the polyethylenes obtained using $\mathrm{Ni4} / \mathrm{MMAO}$ with various $\mathrm{Al} / \mathrm{Ni}$ ratios (entries $1-5$, Table 4 ).

Moreover, with respect to the properties of the polyethylenes, the GPC curves clearly indicate that the polyethylene gradually lowers in molecular weight as the reaction temperature is raised (Fig. 4). This observation would suggest more facile chain transfer and termination at the higher temperature. ${ }^{11,12}$ Similar correlations with reaction temperature can be observed with melting temperature $\left(T_{m}\right)$ of the polymer and molecular weight distribution.

Thirdly, with the temperature set at $30^{\circ} \mathrm{C}$ and the $\mathrm{Al} / \mathrm{Ni}$ ratio at 1750 , the lifetime of active species was investigated. Monitoring the polymerization over run times of $15,30,45$ and 60 minutes (entries 2, $9-11$, Table 4), the activity reached a peak at $3.88 \times 10^{6} \mathrm{~g}(\mathrm{PE}) \cdot \mathrm{mol}^{-}$ ${ }^{1}(\mathrm{Ni}) \cdot \mathrm{h}^{-1}$ after 30 minutes (entry 2 , Table 4 ).

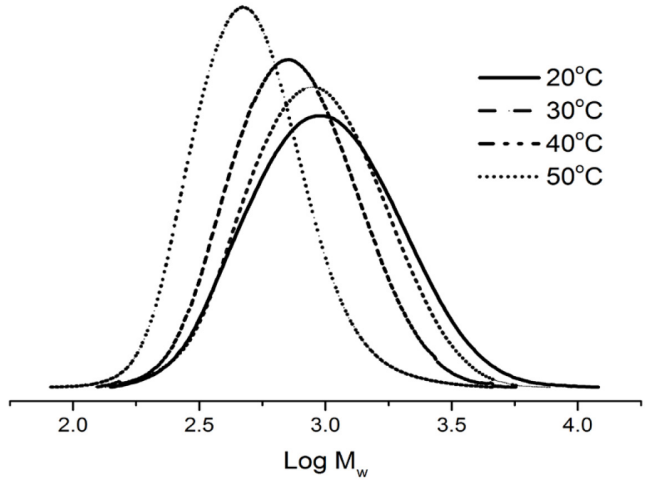

Fig. 4 GPC curves for the polyethylenes obtained using Ni4/MMAO at different temperatures (entries 2, 6-8, Table 4).

Beyond 30 minutes the activity gradually decreased reaching a minimum of $2.71 \times 10^{6}$ $\mathrm{g}(\mathrm{PE}) \cdot \mathrm{mol}^{-1}(\mathrm{Ni}) \cdot \mathrm{h}^{-1}$ after 60 minutes (entry 11 , Table 4). This steady decrease in activity is likely due to partial deactivation of the active species. ${ }^{23}$ Although an alternative explanation may be due to the increased viscosity of the reaction medium over time as more polymer is generated hence limiting the diffusion of ethylene to the active species. ${ }^{21 a}$

Finally, with the optimized conditions established $(\mathrm{Al} / \mathrm{Ni}$ ratio 1750 , run temperature of $30^{\circ} \mathrm{C}$ and a run time of 30 minutes) the other pre-catalysts $\mathrm{Ni1}, \mathrm{Ni2}, \mathrm{Ni3}$ and $\mathrm{Ni5}$ were 
screened for ethylene polymerization (entries $12-15$, Table 4). On inspection of the data the activities of these four catalysts along with $\mathrm{Ni4}$ follow the order: Ni4 [2,4,6-tri(Me)] > Ni1 [2,6$\mathrm{di}(\mathrm{Me})]>\mathrm{Ni5}$ [2,6-di(Et)-4-Me] > Ni2 [2,6$\mathrm{di}(\mathrm{Et})]$ > Ni3 [2,6-di(i-Pr)]. In general, less sterically hindered pre-catalysts with electron donating groups at the para-position favor good catalytic efficiency. ${ }^{24}$ The improved solubility of the para-methylated complexes, $\mathrm{Ni4}$ and $\mathbf{~ N i 5}$, in toluene may also account for better catalytic activities. ${ }^{11(a)}$ Surprisingly, Ni3 containing the bulky o-substituents ( $i-\operatorname{Pr}$ ) showed very low activity (entry 14, Table 4), an observation that can likely be attributed to the sterically hindered $o$-substituents blocking the ethylene monomer from approaching the active center. ${ }^{25}$

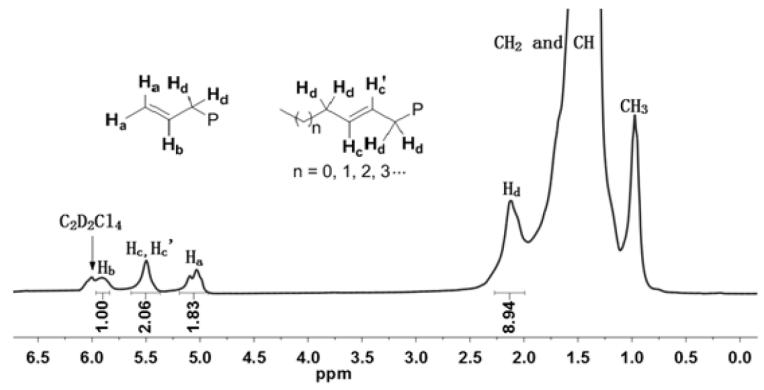

Fig. $5{ }^{1} \mathrm{H}$ NMR spectrum of the polyethylene obtained using Ni4/MMAO (entry 2, Table 4); recorded in $\mathrm{C}_{2} \mathrm{Cl}_{4} \mathrm{D}_{2}$

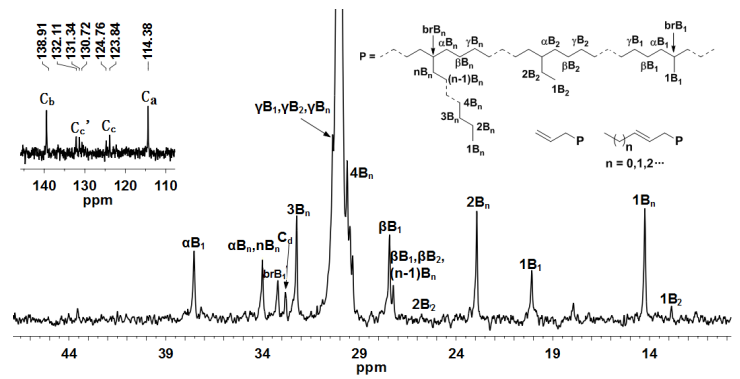

Fig. $6{ }^{13} \mathrm{C}$ NMR spectrum of the polyethylene obtained using Ni4/MMAO (entry 2, Table 4); recorded in $\mathrm{C}_{2} \mathrm{Cl}_{4} \mathrm{D}_{2}$

To investigate the microstructure of these polyethylenes a representative sample generated using Ni4/MMAO was characterized by high-temperature ${ }^{1} \mathrm{H} \mathrm{NMR},{ }^{13} \mathrm{C} N \mathrm{NMR}$ and DEPT135 NMR spectroscopy (recorded in deuterated 1,1,2,2-tetrachloroethane $\left(\mathrm{C}_{2} \mathrm{Cl}_{4} \mathrm{D}_{2}\right)$ at $\left.100{ }^{\circ} \mathrm{C}\right)$. Two downfield peaks $\delta$
5.90 and $\delta 5.00$ in the ${ }^{1} \mathrm{H}$ NMR spectrum (Fig. $5)$ along with peaks around $\delta 114.7$ and 139.9 in the ${ }^{13} \mathrm{C}$ NMR spectrum (Fig. 6) support the presence of a vinyl end-group ($\left.\mathrm{CH}=\mathrm{CH}_{2}\right) .{ }^{25}$ In addition, peaks at $\delta 5.49$ in ${ }^{1} \mathrm{H}$ NMR spectrum are consistent with the presence of internal vinylene groups ($\mathrm{CH}=\mathrm{CH}-$ ) which is corroborated by signals at $\delta 131.0$ and 124.0 in the ${ }^{13} \mathrm{C}$ NMR spectrum. ${ }^{27}$ Further evidence for these assignments is provided by the DEPT135 NMR spectrum (Fig. 7), which shows three positive peaks around 139.0, 131.0 and $123.1 \mathrm{ppm}$ and one negative peak at $114.1 \mathrm{ppm}$. Similar microstructural properties have been noted in the polyethylenes obtained using the 7arylimino-6,6dimethyl-cyclopenta[b]pyridylnickel chlorides (E, Chart 1); a related mechanism to that proposed previously

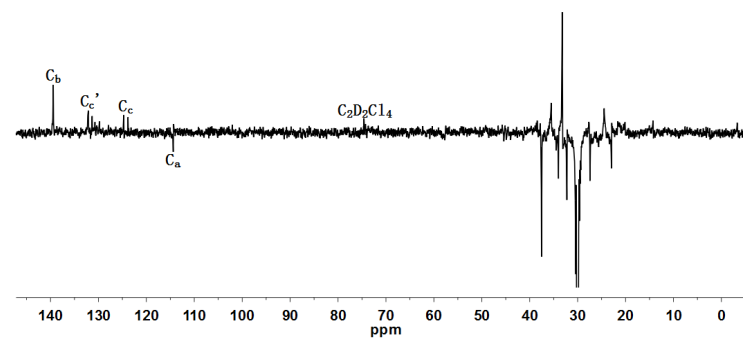

Fig. 7 DEPT135 NMR spectrum of the polyethylene obtained using Ni4/MMAO (entry 2, Table 4); recorded in $\mathrm{C}_{2} \mathrm{Cl}_{4} \mathrm{D}_{2}$

would seem likely to account for the structural features. ${ }^{16} \mathrm{~A}$ branching analysis was also performed on the polymer using the data acquired from the ${ }^{13} \mathrm{C} N M R$ spectrum using methods previously reported. ${ }^{27 b, 28}$ Typically this analysis revealed 34 branches per 1000 carbons and includes $28.0 \%$ methyl branches, $5.1 \%$ ethyl branches and $66.9 \%$ longer chain branches.

\section{Polymerization screen using $\mathrm{Ni} 1-\mathrm{Ni} 5 / \mathrm{Et}_{2} \mathrm{AICl}$}

To explore in more detail the use of $\mathrm{Et}_{2} \mathrm{AlCl}$ as the co-catalyst, $\mathrm{Ni} 4$ was again selected as the test pre-catalyst to ascertain the optimum polymerization parameters to deliver the best activity for the polymerization; the results are 
assembled in Table 5. As a general point, the data reveal similar activities to that observed with MMAO as co-catalyst, however, the polyethylene obtained displays lower molecular weight and narrower molecular weight distributions.

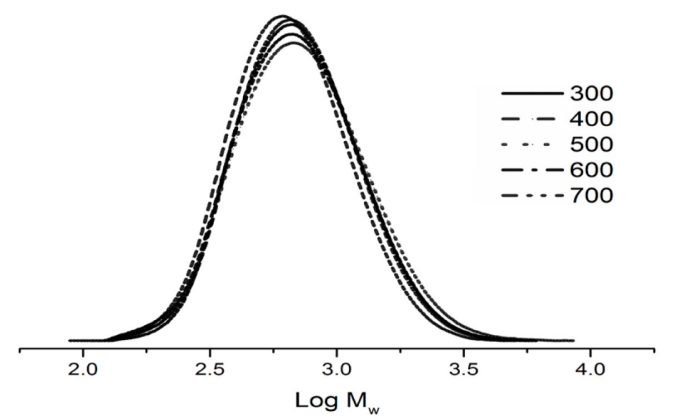

Fig. 8 GPC curves for the polyethylenes obtained using $\mathrm{Ni} 4 / \mathrm{Et}_{2} \mathrm{AlCl}$ with various $\mathrm{Al} / \mathrm{Ni}$ ratios (entries $1-5$, Table 5).

Firstly, the effect of varying the molar ratio of $\mathrm{Al} / \mathrm{Ni}$ on the catalytic activity of $\mathrm{Ni4}$ and other polymer properties was investigated. Typically, the $\mathrm{Al} / \mathrm{Ni}$ ratio was varied from 300 up to 700 with the temperature set at $30{ }^{\circ} \mathrm{C}$ and the run time at 30 minutes (entries $1-5$, Table 5). Examination of the data reveals a peak activity of $3.51 \times 10^{6} \mathrm{~g}(\mathrm{PE}) \mathrm{mol}^{-1}(\mathrm{Ni}) \mathrm{h}^{-1}$ at an $\mathrm{Al} / \mathrm{Ni}$ ratio of 500 (entry 3 ); in addition this ratio also delivers the highest molecular weight of $0.87 \mathrm{Kg} \mathrm{mol}^{-1}$ for these 5 runs. Above 500 the catalytic activities and molecular weight slightly decrease; the molecular weight variation across the five ratios is depicted in the GPC curves in Fig. 8.

Secondly, with the $\mathrm{Al} / \mathrm{Ni}$ ratio maintained at 500 the effect of increasing the reaction temperature from 20 to $50{ }^{\circ} \mathrm{C}$ using $\mathrm{Ni4}$ was explored (entries 3, 6-8, Table 5). As with the $\mathrm{Ni4} / \mathrm{MMAO}$ system, the highest activity of 3.51

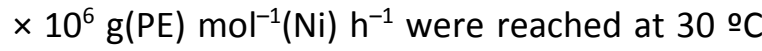
(entry 3, Table 5) above which the activities lowered and quite sharply at $50{ }^{\circ} \mathrm{C}$ (entry 8 , Table 5). At the same time the molecular weight and the $T_{m}$ values of the polymer all decreased (Fig. 9).

Thirdly, with the Al/Ni molar ratio fixed at 500 and the reaction temperatures of $30^{\circ} \mathrm{C}$, the

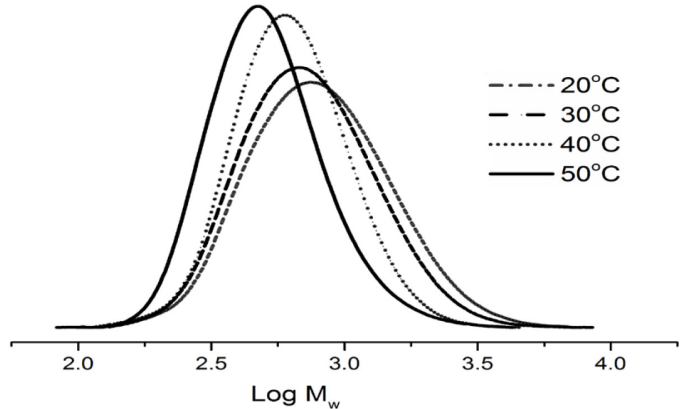

Fig. 9 GPC curves for the polyethylenes obtained using $\mathrm{Ni4} / \mathrm{Et}_{2} \mathrm{AlCl}$ at different temperatures (entries 3, 6-8, Table 5).

polymerization run using $\mathrm{Ni} 4$ was terminated at 5, 10, 15, 30, 45, 60 and 120 minutes (entries 3, 9 - 14, Table 5). As with the earlier study the maximum activity $\left(3.51 \times 10^{6} \mathrm{~g}(\mathrm{PE}) \mathrm{mol}^{-1}(\mathrm{Ni}) \mathrm{h}^{-1}\right)$ was observed after 30 minutes (entry 3 , Table $5)$. Nevertheless, a remarkably smooth profile (in the range $3.28-3.51 \times 10^{6} \mathrm{~g}(\mathrm{PE}) \cdot \mathrm{mol}^{-1}(\mathrm{Ni}) \cdot \mathrm{h}^{-}$ $\left.{ }^{1}\right)$ for the activity was observed from 10 to 60 minutes. Even after 120 minutes the activity had only fallen to $\left.2.12 \times 10^{6} \mathrm{~g}(\mathrm{PE}) \cdot \mathrm{mol}^{-1}(\mathrm{Ni}) \cdot \mathrm{h}^{-1}\right)$. However, the low activity observed after 5 minutes (entry 9, Table 5) implies there is an induction period of about 10 minutes to fully generate the active species before the catalyst reaches its optimal performance. Following optimization of the conditions for $\mathrm{Ni4} / \mathrm{Et}_{2} \mathrm{AlCl}$, the remaining four pre-catalysts were then investigated with an $\mathrm{Al} / \mathrm{Ni}$ ratio 500 , run temperature of $30{ }^{\circ} \mathrm{C}$ and a run time of 30 minutes (entries 3, $15-18$, Table 5 ). In terms of catalytic activity the pre-catalysts fall in the order: Ni4 [2,4,6-tri(Me)] > Ni1 [2,6-di(Me)] > Ni5 [2,6-di(Et)-4-Me] > Ni2 [2,6-di(Et)] >> Ni3 $[2,6-\mathrm{di}(i-\mathrm{Pr})]$. This order mimics that seen in the study with MMAO with $\mathrm{Ni3}$ again showing very low activity and highlighting the preference for low steric bulk and electron donating parasubstituents. Of the five pre-catalysts screened, Ni1 gives the lowest molecular weight of $0.67 \mathrm{Kg} \cdot \mathrm{mol}^{-1}$ and $\mathrm{Ni4}$ the highest of $0.87 \mathrm{Kgmol}^{-1}$ (entries 3 and 15, Table 5). 
Table 5 Catalytic evaluation using $\mathrm{Et}_{2} \mathrm{AlCl}$ as co-catalyst ${ }^{a}$

\begin{tabular}{|c|c|c|c|c|c|c|c|c|c|}
\hline Entry & Precat. & $\mathrm{Al} / \mathrm{Ni}$ & $T /{ }^{\circ} \mathrm{C}$ & $t / \min$ & $\mathrm{PE} / \mathrm{g}$ & Activity $^{b}$ & $T_{\mathrm{m}}{ }^{c} /{ }^{\circ} \mathrm{C}$ & $M_{\mathrm{w}}{ }^{d} / \mathrm{Kg} \cdot \mathrm{mol}^{-1}$ & $M_{\mathrm{w}} / M_{\mathrm{n}}{ }^{d}$ \\
\hline 1 & $\mathrm{Ni4}$ & 300 & 30 & 30 & 2.95 & 1.97 & 67.5 & 0.81 & 1.33 \\
\hline 2 & $\mathrm{Ni} 4$ & 400 & 30 & 30 & 4.47 & 2.98 & 69.0 & 0.81 & 1.33 \\
\hline 3 & Ni4 & 500 & 30 & 30 & 5.26 & 3.51 & 71.1 & 0.87 & 1.39 \\
\hline 4 & $\mathrm{Ni} 4$ & 600 & 30 & 30 & 5.15 & 3.43 & 71.1 & 0.82 & 1.36 \\
\hline 5 & Ni4 & 700 & 30 & 30 & 4.49 & 2.99 & 64.6 & 0.75 & 1.31 \\
\hline 6 & $\mathrm{Ni} 4$ & 500 & 20 & 30 & 4.53 & 3.02 & 88.6 & 0.97 & 1.43 \\
\hline 7 & $\mathrm{Ni} 4$ & 500 & 40 & 30 & 3.42 & 2.28 & 64.8 & 0.71 & 1.27 \\
\hline 8 & $\mathrm{Ni} 4$ & 500 & 50 & 30 & 1.30 & 0.87 & 63.5 & 0.70 & 1.27 \\
\hline 9 & $\mathrm{Ni} 4$ & 500 & 30 & 5 & 0.47 & 1.88 & 72.1 & 0.84 & 1.28 \\
\hline 10 & Ni4 & 500 & 30 & 10 & 1.64 & 3.28 & 71.2 & 0.80 & 1.29 \\
\hline 11 & $\mathrm{Ni} 4$ & 500 & 30 & 15 & 2.49 & 3.32 & 69.1 & 0.80 & 1.29 \\
\hline 12 & $\mathrm{Ni} 4$ & 500 & 30 & 45 & 7.69 & 3.42 & 66.2 & 0.77 & 1.38 \\
\hline 13 & $\mathrm{Ni} 4$ & 500 & 30 & 60 & 10.02 & 3.34 & 75.2 & 0.76 & 1.40 \\
\hline 14 & $\mathrm{Ni} 4$ & 500 & 30 & 120 & 12.74 & 2.12 & 71.6 & 0.82 & 1.39 \\
\hline 15 & Ni1 & 500 & 30 & 30 & 4.62 & 3.08 & 64.1 & 0.67 & 1.32 \\
\hline 16 & $\mathrm{Ni} 2$ & 500 & 30 & 30 & 1.52 & 1.01 & 70.6 & 0.75 & 1.23 \\
\hline 17 & $\mathrm{Ni} 3$ & 500 & 30 & 30 & trace & - & - & - & - \\
\hline 18 & Ni5 & 500 & 30 & 30 & 2.18 & 1.45 & 65.9 & 0.73 & 1.25 \\
\hline $19^{e}$ & Ni4 & 500 & 30 & 30 & 2.35 & 1.57 & 66.1 & 0.79 & 1.32 \\
\hline
\end{tabular}

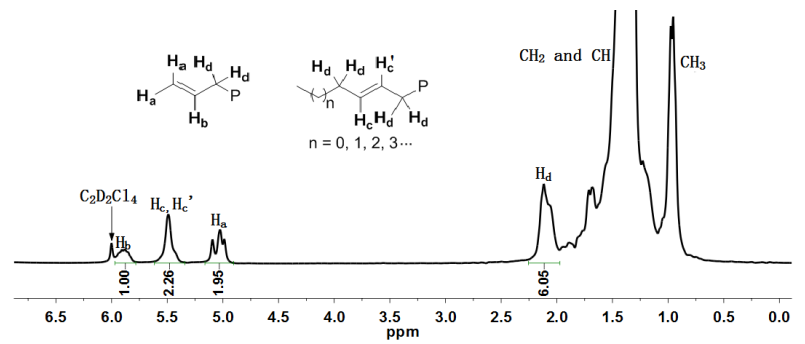

Fig. $10{ }^{1} \mathrm{H}$ NMR spectrum of the polyethylene obtained using Ni4/Et ${ }_{2} \mathrm{AlCl}$ (entry 3, Table 5); recorded in $\mathrm{C}_{2} \mathrm{Cl}_{4} \mathrm{D}_{2}$

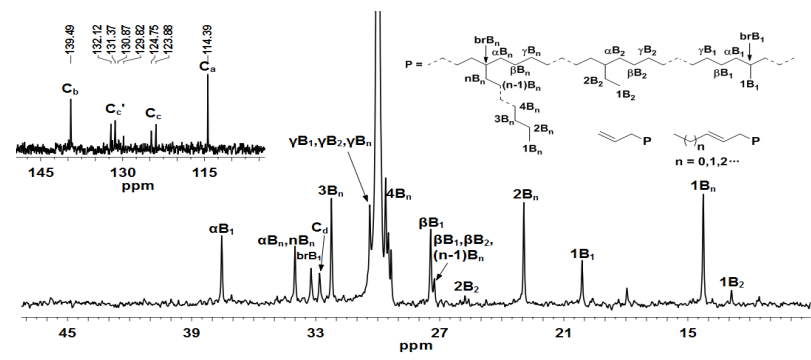

Fig. $11{ }^{13} \mathrm{C}$ NMR spectrum of the polyethylene obtained using $\mathrm{Ni} / / \mathrm{Et}_{2} \mathrm{AlCl}$ (entry 3, Table 5); recorded in $\mathrm{C}_{2} \mathrm{Cl}_{4} \mathrm{D}_{2}$

To confirm the expected structural properties of the polyethylene obtained with this cocatalyst, a sample of the material obtained using $\mathrm{Ni4} / \mathrm{Et}_{2} \mathrm{AlCl}$ (entry 3, Table 5) was subjected to a high-temperature ${ }^{1} \mathrm{H} \quad \mathrm{NMR},{ }^{13} \mathrm{C} \quad \mathrm{NMR}$ and DEPT135 NMR spectroscopic study (Figs. 10 12). Once again, the data reveal the existence of

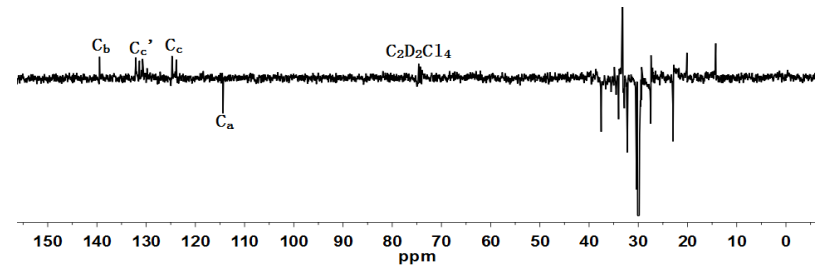

Fig. 12 DEPT135 NMR spectrum of the polyethylene obtained using $\mathrm{Ni} 4 / \mathrm{Et}_{2} \mathrm{AlCl}$ (entry 3, Table 5); recorded in $\mathrm{C}_{2} \mathrm{Cl}_{4} \mathrm{D}_{2}$

unsaturated vinyl and vinylene groups. In addition, the branching analysis based on the ${ }^{13} \mathrm{C}$ NMR data shows 41 branches/1000 carbons, including $26.2 \%$ methyl branches, $6.3 \%$ ethyl branches and $67.5 \%$ longer chain branches, which is comparable to that seen using $\mathrm{Ni} 4 / \mathrm{MMAO}$ (vide supra). ${ }^{276,28}$

Overall, it is apparent that the active bromide-containing pre-catalysts (Ni1, Ni2, Ni4, Ni5) developed in this work form similar low molecular weight polymeric material to that seen using chloride-containing E (Chart 1), albeit with slightly lower activity. However, closer inspection of the data reveal that the current systems show that the absolute molecular weight is lower (as low as 0.67 $\left.\mathrm{Kg} \cdot \mathrm{mol}^{-1}\right)$. Indeed, when compared with other cycloalkyl-fused iminopyridyl-nickel precatalysts (A - E, Chart 1$)$, the current systems afford the lowest molecular weight 
polyethylene for this class of nickel pre-catalyst (Chart 2).

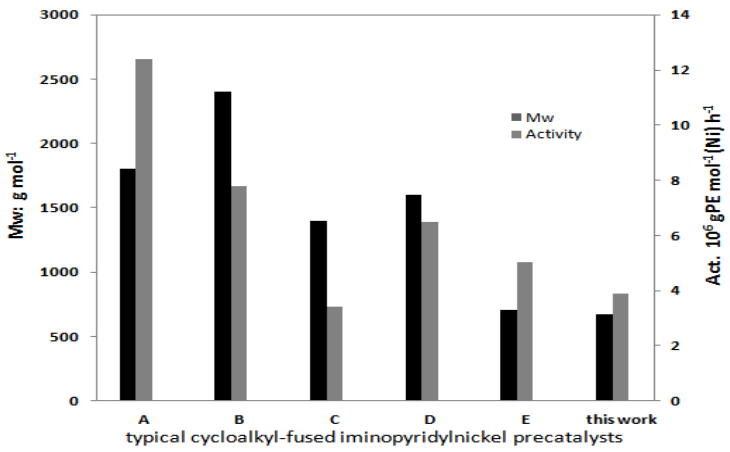

Chart 2 The catalytic performances of cycloalkyl-fused iminopyridyl-nickel precatalysts (A - E and this work)

\section{Conclusions}

Five related imino-cyclopenta[b]pyridyl-nickel(II) bromides (Ni1 - Ni5), differing in the steric and electronic properties of the $\mathrm{N}$-aryl group, were synthesized and fully characterized; the molecular structures of $\mathbf{N i 1}$ ' and $\mathbf{N i 3}$ were also determined. Ni1, Ni2, Ni4 and Ni5 all proved highly active catalysts for the ethylene polymerization on activation with MMAO or $\mathrm{Et}_{2} \mathrm{AlCl}$ (up to $3.88 \times 10^{6} \mathrm{~g}(\mathrm{PE}) \cdot \mathrm{mol}^{-1}(\mathrm{Ni}) \cdot \mathrm{h}^{-1}$ ). Steric and electronic factors play key roles in dictating catalytic performance with the least sterically protected pre-catalyst containing an electron-donating group $\mathrm{Me}$ at the para position (Ni4) delivering the best performance; by contrast the most sterically hindered system (Ni3) showed scarcely any activity. The waxy polyethylenic materials obtained display low molecular weights, narrow molecular weight distributions and contain unsaturated vinyl and vinylene units. Such materials have shown some demand as long-chain branched co-monomers, functionally modifiable polymers as well as for coating materials.

\section{Acknowledgements}

This work was supported by National Natural Science Foundation of China (Nos. U1362204, 21473160, and 21374123). GAS thanks the Chinese Academy of Sciences for a visiting fellowship.

\section{References}

1. L. K. Johnson, C. M. Killian, M. Brookhart, J. Am. Chem. Soc., 1995, 117, 6414-6415.

2. (a) C. S. Popeney, A. L. Rheingold, Z. Guan, Organometallics, 2009, 28, 4452-4463; (b) D. H. Leung, J. W. Ziller, Z. Guan, J. Am. Chem. Soc., 2008, 130, 7538-7539; (c) T. V. Laine, K. Lappalainen, J. Liimatta, E. Aitola, B. Lofgren, M. Leskela, Macromol. Rapid Commun., 1999, 20, 487-491; (d) A. Koppl, H. G. Alt, J. Mol. Catal. A: Chem., 2000, 154, 45-53; (e) S. D. Ittel, L. K. Johnson, M. Brookhart, Chem. Rev., 2000, 100, 11691203; (f) S. Mecking, Coord. Chem. Rev., 2000, 203, 325-351.

3. (a) W.-H. Sun, Adv. Polym. Sci., 2013, 258, 163-178; (b) R. Gao, W.-H. Sun, C. Redshaw, Catal. Sci. Technol., 2013, 3, 1172-1179; (c) S. Wang, W.-H. Sun, C. Redshaw, J. Organomet. Chem., 2014, 751, 717-741; (d) C. Bianchini, G. Giambastiani, L. Luconi, A. Meli, Coord. Chem. Rev., 2010, 254, 431-455.

4. (a) S. A. Svejda, M. Brookhart, Organometallics, 1999, 18, 65-74; (b) T. V. Laine, U. Piironen, K. Lappalainen, M. Klinga, E. Aitola, M. Leskelä, J. Organomet. Chem., 2000, 606, 112-124; (c) C. Shao, W.-H. Sun, Z. Li, Y. Hu, L. Han, Catal. Commun., 2002, 3, 405-410; (d) S. Jie, D. Zhang, T. Zhang, W.-H. Sun, J. Chen, Q. Ren, D. Liu, G. Zheng, W. Chen, J. Organomet. Chem., 2005, 690, 1739-1749; (e) C. Zhang, W.-H. Sun, Z.-X. Wang, Eur. J. Inorg. Chem., 2006, 4895-4902; (f) R. Gao, L. Xiao, X. Hao, W.-H. Sun, F. Wang, Dalton Trans., 2008, 5645-5651; (g) F. Yang, Y. Chen, Y. Lin, K. Yu, Y. Liu, Y. Wang, S. Liu, J.-T. Chen, Dalton Trans., 2009, 1243-1250.

5. (a) C. Wang, S. Friedrich, T. R. Younkin, R. T. Li, R. H. Grubbs, D. A. Bansleben, M. W. Day, Organometallics, 1998, 17, 3149-3151; (b) C. Carlini, M. Isola, V. Liuzzo, A. M. R. Galletti, G. Sbrana, Appl. Catal., A, 2002, 
231, 307-320; (c) S. Wu, S. Lu, Appl. Catal., $A$, 2003, 246, 295-301; (d) F. Chang, D. Zhang, G. Xu, H. Yang, J. Li, H. Song, W.-H. Sun, J. Organomet. Chem., 2004, 689, 936946; (e) T. Hu, L.-M. Tang, X.-F. Li, Y.-S. Li, N.-H. Hu, Organometallics, 2005, 24, 26282632.

6. (a) W. Keim, S. Killat, C. F. Nobile, G. P. Suranna, U. Englert, R. Wang, S. Mecking, D. L. Schröder, J. Organomet. Chem., 2002, 662, 150-171; (b) W.-H. Sun, Z. Li, H. Hu, B. Wu, H. Yang, N. Zhu, X. Leng, H. Wang, New J. Chem., 2002, 26, 1474-1478; (c) F. Speiser, P. Braunstein, L. Saussine, R. Welter, Organometallics, 2004, 23, 26132624; (d) F. Speiser, P. Braunstein, L. Saussine, Organometallics, 2004, 23, 26252632; (e) F. Speiser, P. Braunstein, L. Saussine, R. Welter, Inorg. Chem., 2004, 43, 1649-1658; (f) Z. Weng, S. Teo, T. S. A. Hor, Organometallics, 2006, 25, 4878-4882.

7. (a) L. Wang, W.-H. Sun, L. Han, H. Yang, Y. $\mathrm{Hu}, \mathrm{X}$. Jin, J. Organomet. Chem., 2002, 658, 62-70; (b) N. Ajellal, M. C. A. Kuhn, A. D. G. Boff, M. Hörner, C. M. Thomas, J.-F. Carpentier, O. L. Casagrande, Organometallics, 2006, 25, 1213-1216; (c) S. Adewuyi, G. Li, S. Zhang, W. Wang, P. Hao, W.-H. Sun, N. Tang, J. Yi, J. Organomet. Chem., 2007, 692, 3532-3541; (d) M. Zhang, S. Zhang, P. Hao, S. Jie, W.-H. Sun, P. Li, X. Lu, Eur. J. Inorg. Chem., 2007, 38163826.

8. F. Speiser, P. Braunstein, L. Saussine, Dalton Trans., 2004, 1539-1545.

9. (a) X. Tang, W.-H. Sun, T. Gao, J. Hou, J. Chen, W. Chen, J. Organomet. Chem., 2005, 690, 1570-1580; (b) Q.-Z. Yang, A. Kermagoret, M. Agostinho, O. Siri, P. Braunstein, Organometallics, 2006, 25, 5518-5527.

10. P. Braunstein, Y. Chauvin, S. Mercier, L. Saussine, C. R. Chim., 2005, 8, 31-38.

11. (a) J. Yu, Y. Zeng, W. Huang, X. Hao, W.-H. Sun, Dalton Trans., 2011, 40, 8436-8443; (b) X. Hou, Z. Cai, X. Chen, L. Wang, C. Redshaw, W.-H. Sun, Dalton Trans., 2012, 41, 1617-1623; (c) L. Zhang, X. Hao, W.-H.
Sun, C. Redshaw, ACS Catal., 2011, 1, 1213-1220; (d) Z. Sun, E. Yue, M. Qu, I. V. Oleynik, I. I. Oleynik, K. Li, T. Liang, W. Zhang, W.-H. Sun, Inorg. Chem. Front., 2015, 2, 223-227.

12. (a) F. Huang, Z. Sun, S. Du, E. Yue, J. Ba, X. Hu, T. Liang, G. B. Galland, W.-H. Sun, Dalton Trans., 2015, 44, 14281-14292; (b) Z. Sun, F. Huang, M. Qu, E. Yue, I. V. Oleynik, I. I. Oleynik, Y. Zeng, T. Liang, K. Li, W. Zhang, W.-H. Sun, RSC Adv., 2015, 5, 77913-77921.

13. R. Zhang, Z. Wang, Z. Flisak, X. Hao, Q. Liu, W.-H. Sun, J. Polym. Sci., Part A: Polym. Chem., 2017, 55, 2501-2610.

14. (a) J. Ba, S. Du, E. Yue, X. Hu, Z. Flisak, W.-H. Sun, RSC Adv., 2015, 5, 32720-32729; (b) Y. Zhang, C. Huang, X. Hao, X. Hu, W.-H. Sun, RSC Adv., 2016, 6, 91401-91408.

15. C. Huang, Y. Zhang, T. Liang, Z. Zhao, X. Hu, W.-H. Sun, New J. Chem., 2016, 40, 93299336.

16. Y. Zhang, C. Huang, X. Wang, Q. Mahmood, X. Hao, X. Hu, C.-Y. Guo, G. A. Solan, W.-H. Sun, Polym. Chem., 2017, 8, 995-1005.

17. (a) D. Zhang, E. T. Nadres, M. Brookhart, O. Daugulis, Organometallics, 2013, 32, 51365143; (b) D. H. Camachoa, Z. Guan, Chem. Commun., 2010, 46, 7879-7893; (c) Z. Flisak, W.-H. Sun, ACS Catal., 2015, 5, 47134724.

18. G. M. Sheldrick, SHELXTL-97, Program for the Refinement of Crystal Structures, University of Göttingen, Germany, 1997

19. (a) J. Yu, X. Hu, Y. Zeng, L. Zhang, C. Ni, X. Hao, W.-H. Sun, New J. Chem., 2011, 35, 178-183; (b) W. Chai, J. Yu, L. Wang, X. Hu, C. Redshaw, W.-H. Sun, Inorg. Chim. Acta., 2012, 385, 21-26.

20. (a) C. Wen, S. Yuan, Q. Shi, E. Yue, D. Liu, W.-H. Sun, Organometallics, 2014, 33, 7223-7231; (b) S. Du, Q. Xing, Z. Flisak, E. Yue, Y. Sun, W.-H. Sun, Dalton Trans., 2015, 44, 12282-12291; (c) S. Du, S. Kong, Q. Shi, J. Mao, C. Guo, J. Yi, T. Liang, W.-H. Sun, Organometallics, 2015, 34, 582-590.

21. (a) S. Yuan, E. Yue, C. Wen, W.-H. Sun, RSC Adv., 2016, 6, 7431-7438; (b) Q. Xing, K. 
Song, T. Liang, Q. Liu, W.-H. Sun, C. Redshaw, Dalton Trans., 2014, 43, 7830-7837.

22. (a) D. Gong, W. Liu, T. Chen, Z.-R. Chen, K.W. Huang, J. Mol. Catal. A: Chem., 2014, 395, 100-107; (b) Z. Hao, B. Xu, W. Gao, Y. Han, G. Zeng, J. Zhang, G. Li, Y. Mu, Organometallics, 2015, 34, 2783-2790.

23. W. Zhang, W.-H. Sun, S. Zhang, J. Hou, K. Wedeking, S. Schultz, R. Fröhlich, H. Song, Organometallics, 2006, 25, 1961-1969.

24. (a) W. Zhang, W. Chai, W.-H. Sun, X. Hu, C. Redshaw, X. Hao, Organometallics, 2012, 31, 5039-5048; (b) W.-H. Sun, S. Kong, W. Chai, T. Shiono, C. Redshaw, X. Hu, C. Guo, X. Hao, Appl. Catal. A: Gen., 2012, 447-448.

25. Y. Zhang, H. Suo, F. Huang, T. Liang, X. Hu, W.-H. Sun, J. Polym. Sci., Part A: Polym.
Chem., 2017, 55, 830-842.

26. (a) S. Du, X. Wang, W. Zhang, Z. Flisak, Y. Sun, W.-H. Sun, Polym. Chem., 2016, 7, 4188-4197; (b) G. B. Galland, R. Quijada, R. Rolas, G. Bazan, Z. J. A. Komon, Macromolecules, 2002, 35, 339-345; (c) W.H. Sun, X. Tang, T. Gao, B. Wu, W. Zhang, H. Ma, Organometallics, 2004, 23, 5037-5047.

27. (a) Y. He, X. Qiu, J. Klosin, R. Cong, G. R. Roof, D. Redwine, Macromolecules, 2014, 47, 3782-3790; (b) V. Busico, R. Cipullo, N. Friederichs, H. Linssen, A. Segre, V. V. A. Castelli, G. V. D. Velden, Macromolecules, 2005, 38, 6988-6996.

28. G. B. Galland, R. F. de Souza, R. S. Mauler, F. F. Nunes, Macromolecules, 1999, 32, 1620-1625. 
ZHENG WANG, YOUFU ZHANG, YANPING MA, XINQUAN HU,* GREGORY A. SOLAN,* YANG SUN, WEN-HUA SUN*

\section{Molecular Weight Control of Polyethylene Waxes using a Constrained Imino- Cyclopenta[b]pyridyl-Nickel Catalyst}

Nickel(II) bromide complexes bearing $N, N$-imino-cyclopenta[b]pyridines, upon activation with either MMAO or $\mathrm{Et}_{2} \mathrm{AlCl}$, exhibited high activity towards ethylene polymerization, producing polyethylenes with low molecular weights, narrow molecular weight distributions as well as unsaturated vinyl and vinylene functionalities.

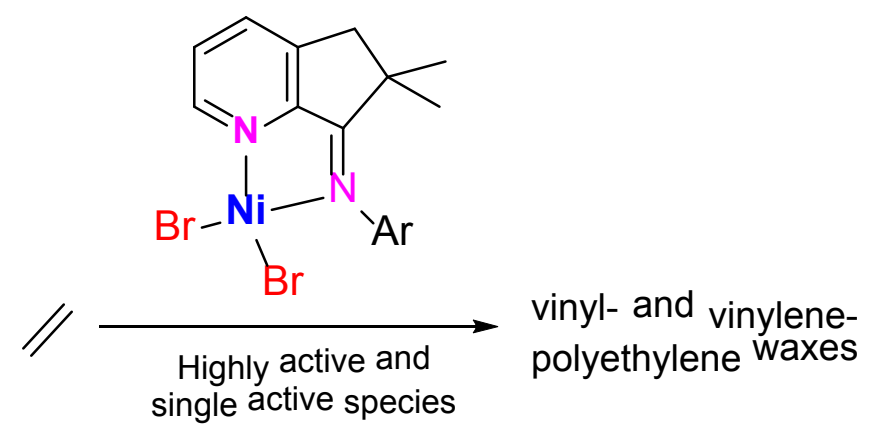

